\title{
Safe Space, Dangerous Territory: Young People's Views on Preventing Radicalization through Education-Perspectives for Pre-Service Teacher Education
}

\author{
Saija Benjamin ${ }^{1, *(\mathbb{D}}$, Visajaani Salonen ${ }^{1}\left(\mathbb{D}\right.$, Liam Gearon ${ }^{2}\left(\mathbb{D}\right.$, Pia Koirikivi ${ }^{1}$ and Arniika Kuusisto ${ }^{1,3}(\mathbb{D}$ \\ 1 Faculty of Educational Sciences, University of Helsinki, 00100 Helsinki, Finland; \\ saivisajaani.salonen@helsinki.fi (V.S.); pia.koirikivi@helsinki.fi (P.K.); arniika.kuusisto@buv.su.se (A.K.) \\ 2 Department of Education, University of Oxford, Oxford OX1 2JD, UK; liam.gearon@ox.ac.uk \\ 3 Department of Child and Youth Studies, University of Stockholm, 11419 Stockholm, Sweden \\ * Correspondence: saija.benjamin@helsinki.fi
}

\section{check for} updates

Citation: Benjamin, S.; Salonen, V.; Gearon, L.; Koirikivi, P.; Kuusisto, A. Safe Space, Dangerous Territory:

Young People's Views on Preventing Radicalization through

Education-Perspectives for Pre-Service Teacher Education. Educ. Sci. 2021, 11, 205. https://doi.org/ 10.3390/educsci11050205

Academic Editors: Kirsi Tirri and James Albright

Received: 29 March 2021

Accepted: 23 April 2021

Published: 27 April 2021

Publisher's Note: MDPI stays neutral with regard to jurisdictional claims in published maps and institutional affiliations.

Copyright: (c) 2021 by the authors. Licensee MDPI, Basel, Switzerland. This article is an open access article distributed under the terms and conditions of the Creative Commons Attribution (CC BY) license (https:// creativecommons.org/licenses/by/ $4.0 /)$.

\begin{abstract}
Initiatives for preventing radicalization and violent extremism through education (PVE-E) have become a feature of global educational policy and educational institutions across all phases, from early childhood to universities, also in Finland. If schools may be regarded as safe spaces here for identity and worldview construction and experiences of belonging, the specific subject matter of PVE-E is also dangerous territory. Not least because of PVE-E's focus on radicalization, but above all because of perceptions of schools being used as an adjunct of governmental counter-terrorism policy. We argue that understanding young people's views on issues related to radicalization and violent extremism is critical in order to develop ethical, sustainable, contextualized, and pedagogical approaches to prevent hostilities and foster peaceful co-existence. After providing some critical framing of the Finnish educational context in a broader international setting, we thus examine young people's views $(n=3617)$ in relation to the safe spaces through online survey data gathered as a part of our larger 4-year research project Growing up radical? The role of educational institutions in guiding young people's worldview construction. Specifically focused on Finland but with potentially wider international implications, more understanding about the topic of PVE-E is needed to inform teacher education and training, to which our empirical data makes some innovative contribution.
\end{abstract}

Keywords: prevention of violent extremism through education; safe space; dangerous territory; teachers' beliefs; teachers' skills; identity; worldviews

\section{Introduction}

The rise of nationalism, the threat of terrorism, and the seeming increase in violent attitudes all appear omnipresent in public debate, in Finland as in other countries. In many countries, children and young people are as often part of the story as the adults. Thus, although there have not been large-scale acts of violence and indeed the incidents classified as terrorism in Finland are scarce, the school shootings in Finnish educational institutions in recent history shocked the nation and left incisions, especially in the collective memory and sense of security of young people [1].

The challenges these developments pose for societies and their educational institutions are growing and becoming more complex [2-5]. As possible approaches for the prevention of violent attitudes, radicalisation, and extremism in education, authorities and scholars from various fields have suggested, for example, peace education [6], citizenship education [7], religious education [8], or fostering of national values [9]. With a focus on promoting non-violent dispositions, increasing awareness and understanding of others, and caring for the welfare of others in a peaceful manner [10], education on peace, democracy, and human rights can be seen as opposite for violence, radicalisation, and extremism, and thus considered as potential means towards combatting and preventing these [11-13]. 
Human rights and the international system that supports them have, however, also been characterized and critiqued as being themselves part of the problematics of a dominant global north, and this a source of conflict and dissent $[14,15]$. This has become especially apparent in recent debates around "decolonising the curriculum" [16].

Contentious matters aside, the issues of violence and extremism are never actually far from the surface of international educational policy. Yet, while traditions of human rights and cultural understanding have a long tradition in Finnish education [17], policy and research on the prevention of violent extremism, physical and ideological, has become a new phenomenon in Finland, as it has worldwide [4,18,19]. Rather novel as a specific field of study, the manner in which PVE-E has emerged is quite extraordinary, though the jury, so to speak, is out on the actual effectiveness of such programmes, including in teacher education and training [20]. Many questions therefore remain open when it comes to the prevention of violent extremism through education (PVE-E) in the institutional context, especially in the pedagogical sense.

In sum, initiatives for the countering and preventing violent extremism through education (PVE-E) have become a feature of global educational policy and educational institutions across all phases, from early childhood to universities. If schools may be regarded as safe spaces here for a pastorally sensitive reflection on matters of child safety and harm, the specific subject matter of PVE-E is also dangerous territory. Not least because of PVE-E's focus on radicalization, but above all because of perceptions of schools being used as an adjunct of governmental counter-terrorism policy. For the purposes of developing pre-service teachers' knowledge here-PVE-E policies now involving the educational systems they will enter-understanding young people's views on issues related to radicalization and violent extremism form, we argue, a critical element in policy and pedagogical critique. After providing some critical framing of the Finnish educational context in a broader international setting, we thus examine young people's views in relation to these issues, data gathered as a part of our 4-year research project Growing up radical? The role of educational institutions in guiding young people's worldview construction. Specifically focused on Finland but with potentially wider international implications, more understanding about the topic of PVE-E is needed to inform teacher education and training, to which our empirical data makes some innovative contribution.

\section{Worldviews and Values in Finnish Education}

Education, especially through the formal system of schooling, is one of the core processes through which communities, such as nations, socialize their younger generations and thereby also create and maintain societal cohesion. By transmitting those values and ideas that the society regards important, formal education strengthens the idea of a collective identity and the unity of the group, such thinking is increasingly an important part of international educational policy, including but extending far beyond programs of citizenship [21,22].

Often with a pervasive multidimensional dimension of inherited and acquired culture, worldview is here referred to as an individual's unique ontological, epistemological, and ethical orientation to the environment [23] and the ontological foundation for values, beliefs, and knowledge used in meaning-making and for making choices [24]. Worldview functions as a philosophy of life, which is in a critical role in understanding reality and in providing satisfying meanings to life questions. It may also refer to group values and epistemologies, which function to define understandings of what can be known and how to construct ideas of oneself and "the other" $[25,26]$. Children and youths' worldviews are increasingly hybrid in nature, merging elements from a variety of religious, secular, etc. sources or traditions [27], and new forms of often very individualized spirituality [28,29].

To discuss prevention of radicalization and extremism, in other words, countering of worldviews and mindsets that are considered as harmful or dangerous and thus preventable, it is necessary to first define those values and worldviews that are considered as normative and accepted and in line with societal status quo [4]. Finland's educational 
system is based on an ethos of equality and inclusion [30,31]. There are very few private schools in Finland and all levels of pre-primary, basic, upper secondary, and university education are publicly funded and aimed to be inclusive of all children. School education in Finland is based on the values of humanity, equity, and democracy, stated in the National Core Curricula [31]. While the foreign-born population is still relatively small [32], plurality of attitudes and worldviews is increasing in Finland, which is also demonstrated by the growing demand for school education in different religions and mother tongues, which are offered for pupils based on their guardian's request [33]. The Finnish model of religious and secular ethics education has been praised for the ways in which it supports the freedom of religion identified in the universal declaration of the human rights [34]. However, the model has also been strongly criticized for separating the students according to their memberships, as well as for the fact that students do not necessarily identify themselves with the tradition they are assigned to [35]. Although the school system is officially non-denominational, Finland has a strong connection to the Evangelic-Lutheran church in its history and this has created a national hegemony that, despite secularization, impacts several layers of the society, including basic education. Despite the remarkable decrease in memberships of the Lutheran Church in the past decades, a vast majority of Finns (71\%) affiliate with Lutheranism [36] at least nominally, and consider Lutheranism as part of "Finnishness". While this percentage does not necessarily tell much about the ways in which people identify as being religious or non-religious, it provides an example of the hegemonic position that Christianity has had, and still has, in being the main religious tradition in Finland.

While the objectives of school education are defined in the national curricula, in reality, educational institutions and individual teachers have great autonomy to decide the teaching practices and learning contents. This type of setting emphasizes the significance of individual teachers and their subjective values, worldviews, and understandings about the moral foundations and complexities of those of the others. Unconscious or conscious, these moral and ethical underpinnings underlie all education, from planning to pedagogical practices to assessment. Especially central they become when addressing sensitive, topical themes in the classroom, which lie at the basis of education for the prevention of radicalisation and extremism $[37,38]$.

\section{Prevention of Radicalization in Finnish Education}

Extremism and terrorism receive amplified media attention in Finland as elsewhere in the Western world [39], which shows, for example, in young people's increased worry about terrorism $[40,41]$ and the government's emphasis of the role of the educational sector in the national action plan for prevention of radicalisation and violent extremism [4,42]. Although studies show that the majority of young people in Finland are doing well [43,44] and that violent crime among young people has decreased [45], the suggested responsibilities for educational institutions to partake in the national prevention of radicalisation and extremism is well grounded: societal polarization, various extremist movements, and attacks are in the rise $[46,47]$ and young people's exposure to propaganda, disinformation, racism, and hate speech has increased. Teachers-working and interacting with young people on a daily basis-are at the forefront of these trends as they get to witness and address first-hand the effects and consequences that the various conspiracy theories and extremist ideologies spreading online may have on children and youth.

However, to implement PVE-E policies in schools is not straightforward a mission, as, for example, in the light of the increasing value and worldview pluralism in the Finnish society and classrooms, it becomes challenging for the teachers to define the kinds of values and ideologies that should be endorsed and what should be proscribed in formal education. This ambiguity is reinforced by public debates where the focus of tolerance is often narrow - the social norms and the societal spectrum of normality, especially regarding values (see [48]), pose limits to which group or worldview is promoted, and which ones are perhaps merely "tolerated", or discriminated against [49]. Obviously, there is a lot of 
variety and nuance in between any ideological or religious extremes, so a clear demarcation of worldviews that are endorsed in education and those regarded as extremist and harmful needs careful consideration.

Our previous studies highlight the need to plan PVE-E strategies in line with national educational policies through what we conceptualize as "institutional habitus" [4,18]. This means that, for example, in the Finnish context, strategies based on profiling or monitoring students, deployed in some countries [50], may not seem on the surface appropriate for the Finnish educational culture, which is based on trust and the values of humanity, equity, and democracy $[4,30,31]$. Regardless of interpretation or worldview, human rights and nonviolence can be considered as an indisputable frame of reference when defining models of thought and action that need to be prevented at school. These are also included in the fundamental rights defined by the Finnish constitution, on which the value base and curricula of formal education are based. In this light, it can be concluded that all values, beliefs, and intentions that are contrary to the fundamental rights and curricula and that may lead to violent speech and/or actions should be considered as preventable. Despite these clear boundaries, a lot of interpretive variation remains regarding the ways certain values are held, for example, patriotism and nationalism.

In the national action plan for PVE-E, the role of formal education is viewed as twofold: on the one hand, children and young people must be encouraged to think critically and learn to peacefully engage in democratic citizenship, but on the other hand, attitudes and activism must be prevented from turning into violent acts and extremism [42]. As the objectives of the core curricula and the suggested PVE-E strategy are well aligned, the focus of PVE-E is set on the prevention of polarization of children's and young people's attitudes through a holistic approach based on the objectives and contents already defined in the national curricula and existing organizational structures in ways that strengthen each students' inclusion, well-being, identity construction, and critical thinking [42,51].

Our recent studies on Finnish upper secondary and vocational school students (ages 16 to 20 ) indicate that the Finnish students share these national strategic aspirations. The findings indicate that the students themselves see the role of educational institutions as central in the prevention of violent attitudes and radicalization. The first of these studies [18] examined upper secondary school students' answers to a matriculation examination question titled "Assessing Radicalization" (ages 16 to 20,n=1675). Of particular interest in the research analysis was the way young people see the role of school in the prevention of radicalization. The findings showed that young people see social and educational inequalities as explanatory factors for radicalization and perceive school as an enabler of social equity. In this sense, the students' answers seem to reflect and be in line with the societal ideal, as traditionally in Finland, educational institutions are viewed as contexts where children and young people from all backgrounds meet as equal individuals and acquire equal opportunities in life. Students also stressed the importance of education in increasing one's cognitive capital. They emphasized the need to broaden and diversify one's epistemic foundation, meaning knowledge about different cultures and religions, and skills needed to assess knowledge, such as critical thinking and media literacy. These, the students think, allow for perspective-taking and more independent thinking, which they view as key factors in the prevention of radicalization. Several studies support this idea [3,52,53], and similar skills have been highlighted in several other national prevention strategies [54]. The students also brought forth the significance of school as a social environment. They viewed ostracism as a predisposing factor to radicalization, and related to this, pointed to experiences of bullying and discrimination in school in particular. Combating and preventing bullying and discrimination were considered important in order to experience the school as a safe and inclusive environment in which all learners can grow towards full membership in society. According to our results, the students held that together with teacher-led discussions on different values, worldviews and sensitive issues, the fostering of students' independent thinking and feeling of school belonging could work as effective antidotes to radicalization and extremism. 
In a subsequent study [43], we examined Finnish upper secondary school and vocational school students' (ages 16 to 20, $n=3617$ ) views on how education could prevent and reduce the formation of violent attitudes among young people, and instead, promote attitudes that convey acceptance of diversity and equality between different people. Again, the findings showed that the students regarded access to unbiased information about other people, religions, and ideologies as key to reduce violent attitudes. The findings also brought forth that the students were aware that the information they receive from different sources, including teachers, may be distorted, fake, or presented from a biased perspective depending on the worldview of the speaker. This highlights the topical global concern about the reliability of knowledge and the confusion related to the trustworthiness of different sources of information (see e.g., [55]). The students were cognizant of a need to strengthen their abilities to critically interpret and evaluate knowledge. To do this, they called for settings where all topics and sensitive issues could be evaluated, criticized, and scrutinized together with the teacher safely and calmly from multiple viewpoints. Related to this, the students underlined the importance of learning how to negotiate and debate and other skills related to reconciliation and conflict resolution [43].

While the students recognized broadening one's epistemic foundation as key to reduce violent attitudes, the findings also highlighted the role of the school as a social community. Students underlined the importance of exposure and contact between different students, as social encounters and contact between different people within the school were perceived to reduce hostility and prejudices—-thereby, their views are aligned with Allport's (1954) classic contact hypothesis theory [56]. According to the students, fostering the feeling of togetherness would be a way to counter bullying and violent attitudes, to reduce loneliness and enhance openness to the other. This could be done, as proposed by students, for example, by mixing the students in projects during classes and organizing school-wide events engaging all students and staff. Interaction was seen as important, because according to the students, loneliness and ostracism increase hostility towards others. These findings thus show that a mere increase in epistemic knowledge does not suffice for fostering positive intergroup attitudes among youth, but suggest that the development of a "sense of belonging to a broader community and common humanity", posited as an essential objective for education for a sustainable future by Unesco [57], necessitates positive and inclusive experiences and practices within the school context.

\section{Schools as Safe Spaces: Thinking through Dangerous Territory}

There is much literature on the notion of cultural space [58,59]. In educational terms, there are corresponding notions of schools as safe spaces $[60,61]$. Yet, there are tensions here and this is contested subject matter. Davies [50] (2016) asks, for instance, is all this talk of security and indeed safety about safeguarding or surveillance? Thus, along with the many challenges to introducing notions of security in educational environments, the notional idea of school as a safe space for consideration of challenging topics means the same space represents an encounter with dangerous territory.

Prevention of radicalization and extremism are typically approached from the perspective of counter-terrorism and public safety, one which increasingly impacts all aspects not only of European but global public policy on security [62-64]. Consequently, this has had an impact on many PVE-E strategies where aspects of safety and security have gained increasing prominence [62,65-67]. International debates have long been dominated by openings that consider how - but also increasingly why — educational institutions should detect and identify individuals who are thought to threaten the safety of others with their values or behaviours, or be at risk of "radicalizing" [4,54,68].

This is where the notion of dangerous territory becomes relevant. The types of approaches that focus on monitoring and profiling of the students are often contested, seeming inimical to the ethos of the local education, and across Europe, teachers share some key concerns related to the suggested PVE-E duties [68]. According to studies, identification and reporting duties seem to have increased the prejudices and stigmatisation concerning 
students from certain ethnicities and religious groups [50,69]. In some cases, false alarms from school have led to further investigations and interrogations by the authorities, which create stigma and a psychological burden for the student in question [70,71].

Most importantly, teachers seem to be worried about the apparent contradiction between the curricular objectives to foster students' critical thinking and the duties to report observations about certain student rhetoric or utterances that seem to dispute the curricular or national values. From the students' perspective, the fears of being labelled as radicalised have limited the scope, depth, and possibilities of educational discussions on sensitive topics that students want to engage in class and prevented some of them from seeking psychological support from the school's well-being personnel in the fear of stigma [71-75]. Overall, the PVE-E policies approached from a monitoring perspective may heavily undermine the trust of the students and their families in the teachers and the education system as a place of support and help, and have a long-term toll on the well-being of the students $[2,5,68,76]$. The lack of trust and higher thresholds for seeking socio-emotional support may indeed hinder the general feeling of safety in educational institutions and increase the risk of radicalisation.

Although the Finnish approach to PVE-E is based on fostering well-being and independent thinking instead of assessing risks, the concept of safety, however, emerges as an important concept related to PVE-E in Finland, too. There are classic tensions here in education as elsewhere between notions of liberty, freedom of expression, and the concerns of security. The students in our two studies thus emphasized the school context as a space to learn, explore identities, and scrutinize and understand sensitive topics safely and without a fear of being bullied, excluded, or ridiculed. In this sense, "safety" refers to a "safe space", which is an educational metaphor for spaces concerned with psychological and social benefits and avoidance of harms $[77,78]$. "Safe space" as a notion has roots in Bhabha's $[79,80]$ "third space" $[65,81]$. In the educational context, safety is therefore not something that is controlled and imposed from above, but more a feeling emanating from the actors, organizational practices, and ethos of the school environment.

Similar to the concept of safe space, [82] Cavanagh et al. talk about "culture of care" in schools, referring to an explicit recognition of the plurality of values, beliefs, and practices at school, which makes it feel safe for all students to engage, contribute, belong, and feel confident in their own cultural identities [82]. Na'ilah Suad Nasir and Jasiyah Al-Amin [83] write about educational institutions' necessity to function as identity-safe spaces, also for the religious minority students for whom negotiations of religious values in the societal sphere often are "at once intensely private and painfully public" (see also the REDCo project on European youth, $[65,81,84])$.

In previous research on educational interventions that support student well-being and feelings of safety in school contexts $[60,85,86]$, it is noteworthy that the findings often come down to two main ideas-to support the inclusion and sense of belonging of all students, and to provide opportunities for active, responsible, and meaningful participation. This is comprehensible when taken into account that school contexts that support inclusion, belonging, and opportunities for participation support the satisfaction of the basic psychological needs of the students, namely, autonomy, competence, and relatedness $[87,88]$. Teachers may foster the satisfaction of these needs by minimizing pressure and control on them, conveying warmth, caring, and respect to the students and acknowledging students' feelings about meaningful topics [88].

\section{Educational Institutions and Extremism: Young People's Views}

For the purposes of developing pre-service teachers' own knowledge here-PVE-E now involving the educational systems they will enter-young people's views on issues related to radicalization and violent extremism form here an important part, we argue, in understanding issues in and difficulties with the implementation of such policies. Specifically focused on Finland but with potentially wider international implications, more 
understanding about the topic of PVE-E is needed to inform teacher education and training, to which our empirical data makes some innovative contribution.

Outlining schools and classrooms as safe spaces for identities and dialogues is necessarily an important starting point, but in order to draft a more multidimensional picture of the youths' aspirations concerning the safe space, we here assess the topics the youth want more knowledge and discussions about. To do this, we introduce the methodological framework of our 4-year research project Growing up radical? The role of educational institutions in guiding young people's worldview construction and outline the specificities of the sub-study presented in this paper. For the purposes of the present study, we examined young people's views in relation to the research question: What are the sensitive topics that should be addressed within the safe spaces provided by the school?

\section{Data and Method}

As part of a larger mixed-method study looking at the ways educational institutions can guide young people in their worldview construction and prevent violent attitudes and actions, we carried out an online survey in several Finnish general upper-secondary schools and vocational institutions (16- to 20-year-old students) in eight municipalities across Finland. The survey consisted of both quantitative and qualitative questions about the students' values, social relationships, views about their life, and their perceptions about other people. A total of 3617 respondents answered the questionnaire during autumn 2019. While the qualitative and other quantitative data are reported in other studies, the sub-study presented in this paper focuses specifically on exploring the answers to one previously unexplored quantitative measure.

Of all respondents of the study, $52 \%$ were female and $42 \%$ were male, and $5 \%$ identified either as "other" or did not want to specify their gender. The race or ethnicities of the respondents were not recorded, as this is not a normative procedure in Finland. The share of responses gained from upper secondary institutions was higher than that from vocational settings, with $82 \%$ representation of upper secondary institutions in comparison to $18 \%$ from vocational settings (the sample is thus not nationally representative, as in 2020, the national distribution of students' school choice after basic education was 54\% (upper secondary schools) and 40\% (vocational institutions) [89]). Geographically, the majority of responses $(45 \%)$ were gained from the Helsinki capital area.

We obtained ethical approvals for the study from the Universities of Helsinki and Oxford and by all of the municipalities in which the educational institutions were located. School headmasters or teachers distributed the link to the survey to the students, but it was highlighted that participation was completely voluntary. Parental consent was not needed because of the age of the respondents. The survey began with a confirmation of voluntariness and full anonymity, explanation of the purpose of the study, and reminder of the right to withdraw from responding at any moment.

To discuss approaches to PVE-E in a pedagogical framework, in the present sub-study, we set to examine the students' perspectives about the role of school in the distribution of knowledge on topics closely related to the theme of radicalization and extremism. For the purposes of the present study, we looked at student responses to the following survey question: "How well has school provided you with knowledge on certain topics, namely, 'religions and worldviews', 'well-being and health, 'extremism and terrorism', and 'peace promotion and conflict resolution' on a scale 1 (poorly) to 5 (very well)?" The students' evaluations provided us with an understanding of those topics that, on the one hand, are well covered and addressed in school, and on the other, of those topics that are sensitive and topical, but that are not sufficiently addressed. Concerning the statistical methods to analyse the data, Chi-square test was used as a tool to determine the proportion differences among groups. Variance analysis ANOVA was used to compare the statistical differences among means of groups. Statistical analysis was made with IBM SPSS Statistics (Version 25) predictive analytics software. 


\section{Results}

The online survey included a question about the students' evaluations of the amount of knowledge they have received on certain topics during their school years, namely, about "religions and worldviews", "extremism and terrorism", "peace promotion and conflict resolution", and "well-being and health". Figure 1 shows the proportions by school type, "High school" meaning academically oriented upper secondary institutions and "Vocational" standing for the vocational institutions.

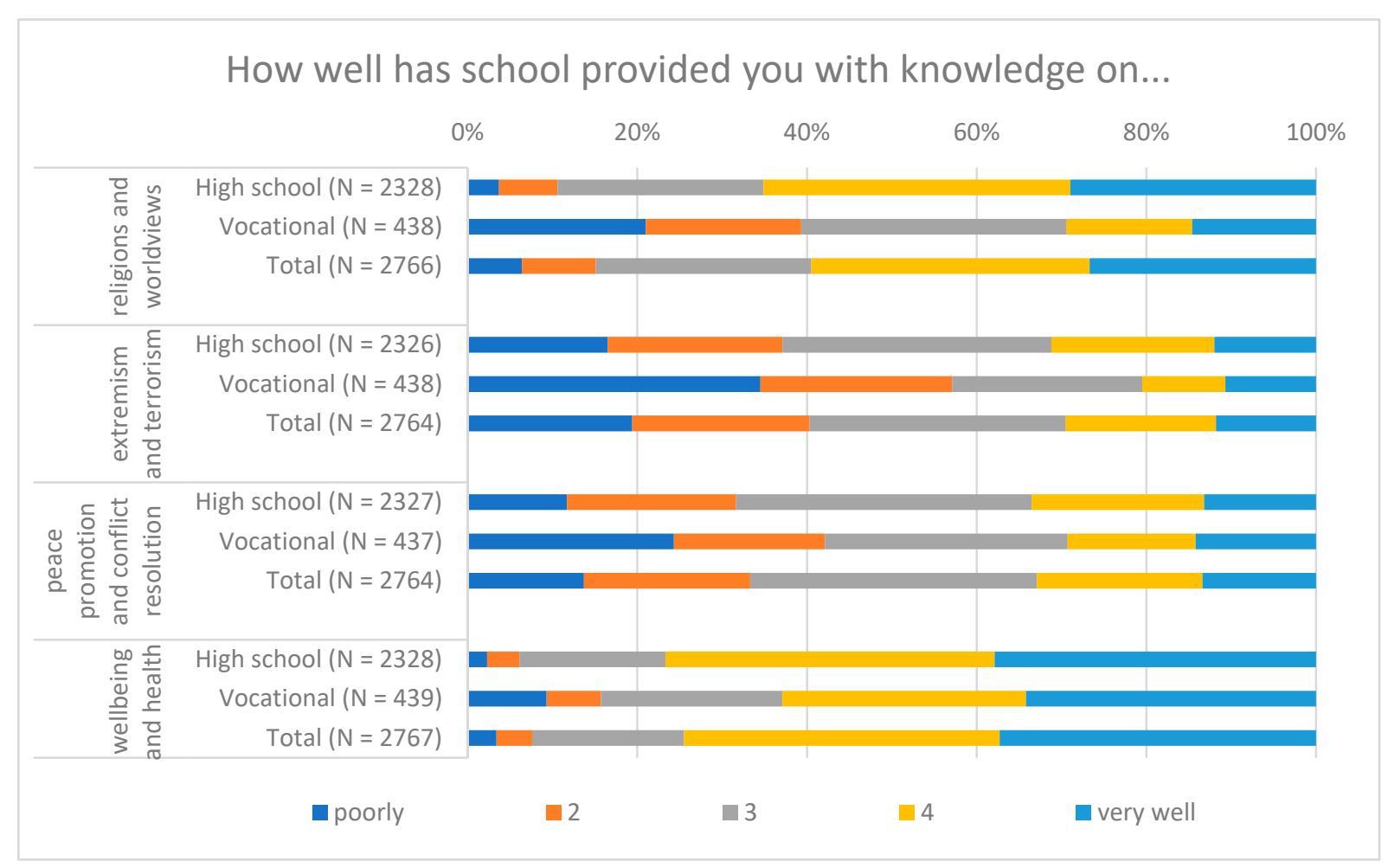

Figure 1. Evaluation of the knowledge received at school, proportions by school type.

When looking at the means and percentages in Figure 1 and Table 1, it can be deducted that of the four topics, the most knowledge the students had received was on religions and worldviews. Sixty percent of the respondents consider that school has provided them information about these "well" or "very well", while only 15\% of them think that it was not enough. This is logical, considering that religious education or secular ethics education are compulsory subjects in school from the first grade on, so by the time the students are in secondary education, they have received a minimum of 9 years of religious or secular ethics education [90]. Similarly, $74 \%$ of the students considered having received "well" or "very well" knowledge about well-being and health in school, while only $7 \%$ of them did not consider it enough. This can also be explained by the fact that health education is a compulsory subject in middle school and the themes related to it are also partly covered in the lessons of physical education. Well-being and health-related themes are also part of the mandatory courses in both upper secondary and vocational institutions.

When looking at the more sensitive topics, 33\% of the students view that school has given them "well" or "very well" information about peace promotion and conflict resolution and $30 \%$ think the same about the topics of extremism and terrorism. However, when viewed the other way around, the results show that $34 \%$ of the students think they have not received enough knowledge about peace promotion and conflict resolution and $40 \%$ of them consider the knowledge school provided about extremism and terrorism has not been adequate. This means that more than every third student would want to 
receive more knowledge and thus, understanding, about these often controversial and emotion-laden topics.

Table 1. Means for selected variables by school type.

\begin{tabular}{ccccccccc}
\hline & \multirow{2}{*}{ Religions and Worldviews } & \multicolumn{2}{c}{$\begin{array}{c}\text { Extremism and } \\
\text { Terrorism }\end{array}$} & \multicolumn{2}{c}{$\begin{array}{c}\text { Peace Promotion and } \\
\text { Conflict Resolution }\end{array}$} & \multicolumn{2}{c}{ Well-Being and Health } \\
\hline & Mean & SD. & Mean & SD. & Mean & SD. & Mean & SD. \\
\hline $\begin{array}{c}\text { High } \\
\text { school } \\
\text { Vocational }\end{array}$ & 3.8 & 1.049 & 2.90 & 1.236 & 3.03 & 1.183 & 4.06 & 0.951 \\
\hline Total & 2.84 & 1.317 & 2.40 & 1.332 & 2.77 & 1.349 & 3.72 & 1.256 \\
\hline
\end{tabular}

When looking at the results by school type, the Chi-square yielded statistically highly significant differences between the school types on evaluations of the knowledge provided in all selected topics (religions and worldviews: $X^{2}(4)=313.6, p<0.001$; extremism and terrorism: $X^{2}(4)=91.7, p<0.001$; peace promotion and conflict resolution: $X^{2}(4)=52.5$, $p<0.001$; well-being and health: $\left.\mathrm{X}^{2}(4)=75.5, p<0.001\right)$. As presented in Table 1, upper secondary general school students had statistically highly significantly higher mean in every selected variable compared to vocational school students (religions and worldviews: $\mathrm{F}(1 ; 2764)=283.70, p<0.001$; extremism and terrorism: $\mathrm{F}(1 ; 2762)=58.62, p<0.001$; peace promotion and conflict resolution: $\mathrm{F}(1 ; 2762)=17.38, p<0.001$; well-being and health: $\mathrm{F}(1 ; 2765)=43.21, p<0.001)$. The differences between school types reflect more generally the divergent curricula and organizational practices in upper secondary schools and vocational institutions. While general education is emphasized in the former with a large offer of academic courses, the culture of vocational institutions is more focused on learning of professional skills [91]. Of course, we cannot deduct from the answers whether the respondents' evaluations were based on the entirety of their school paths or just the current educational context.

The most significant differences between upper secondary and vocational institutions can be viewed at the level of knowledge provided about religions and worldviews. Partly it can be explained by the fact that religious education (RE) is not studied in vocational institutions, but in upper secondary schools, there are two obligatory courses on RE. As Ghosh et al. [20] have shown, the cultural and religious dimension to countering extremism is important, but it is here as equally important to avoid the automatic association of religion with extremism [92]. In terms of the data, though, the place and portrayal of religion in the curriculum is important. There are thus statistically significant differences between the school types on knowledge provided about extremism and terrorism and peace promotion and conflict resolution as well, but they are relatively smaller. These are topics that are not covered as separate entities in the curricula, but typically addressed within the subjects of history, civics, or philosophy, for example. However, as the teachers in Finland have substantial autonomy in the planning of their lessons, including the methods and materials used, the extent and depth to which these, or any other themes, are covered varies greatly from one teacher to the other, according to their motivation (see e.g., [93]).

When looking at the results by gender classification in Figure 2, the Chi-square yielded statistically highly significant differences depending on gender on evaluations of the knowledge provided in all other topics than religions and worldviews (religions and worldviews: $\mathrm{X}^{2}(8)=9.4, p=0.338$; extremism and terrorism: $\mathrm{X}^{2}(8)=28.7, p<0.001$; peace promotion and conflict resolution: $X^{2}(8)=25.7, p=0.001$; well-being and health: $\left.X^{2}(8)=37.2, p<0.001\right)$, again reflecting the role of religious education in the Finnish basic education. As presented in Figure 2, in statistical analysis of means, girls have similar evaluations of the knowledge provided compared to those who do not want to tell their gender or determined themselves as other. The only statistically small difference was found in knowledge offered of well-being and health $(\mathrm{F}(1 ; 1615)=6.749, p=0.016)$, with 
girls evaluating having received more information of it than those who identify as other or do not want to tell their gender. This is understandable, as those students whose gender identity deviates from the normative ones do not receive as much institutional or social support in their identity building as do girls and boys [94].

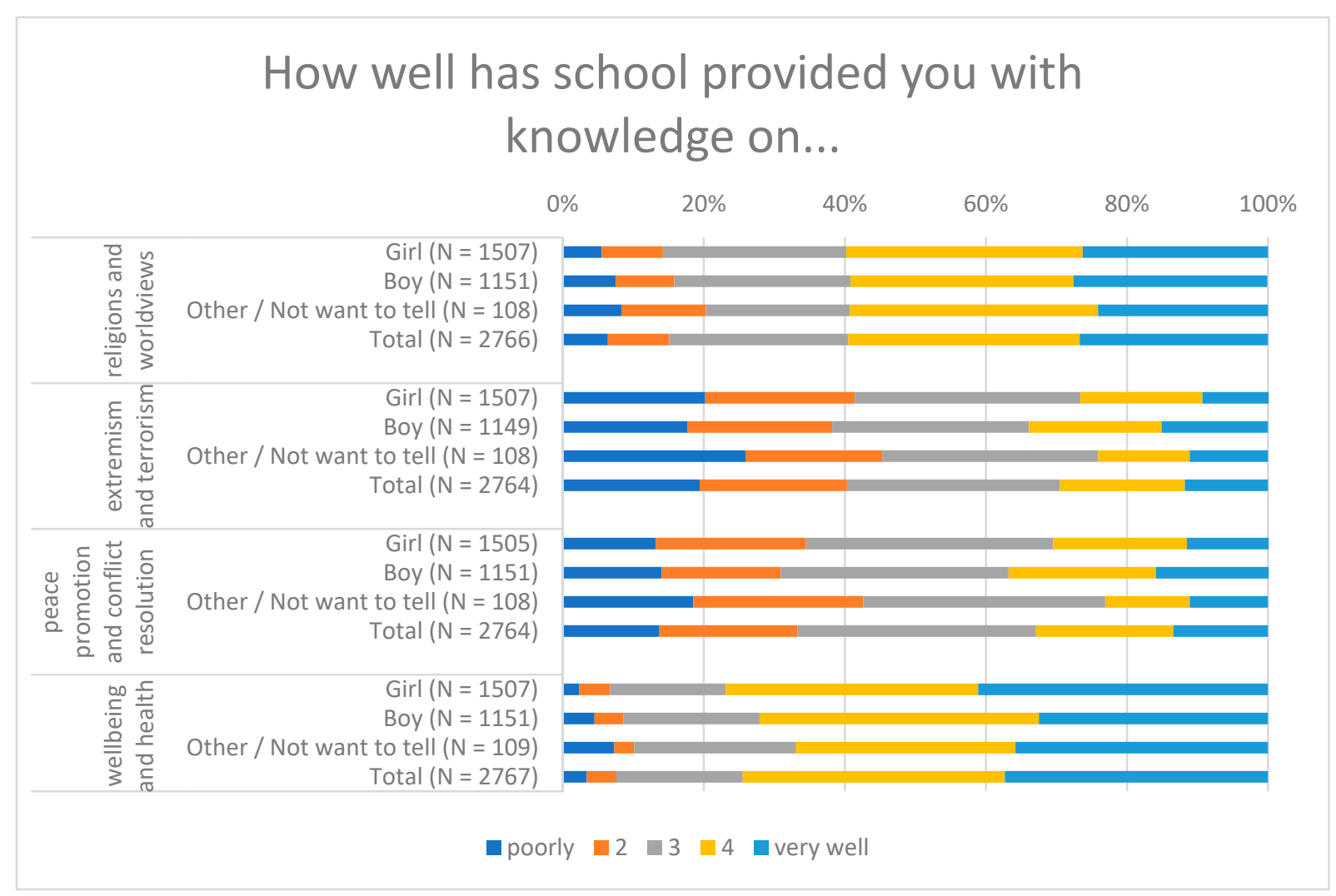

Figure 2. Evaluation of the knowledge received at school, proportions by gender.

Girls had statistically highly significantly lower mean in extremism and terrorism $(\mathrm{F}(1 ; 2659)=3.496, p<0.001)$, statistically highly significantly higher mean in well-being and health $(\mathrm{F}(1 ; 2659)=1.567, p<0.001)$. Also, girls evaluated the knowledge provided of peace promotion and conflict resolution statistically significantly lower than boys by means $(\mathrm{F}(1 ; 2654)=7.952, p=0.004)$. Boys had statistically significantly higher mean on evaluations of the knowledge provided of peace promotion and conflict resolution $(F(1 ; 1257)=0.003$, $p=0.006)$ and statistically significantly weakly higher mean in extremism and terrorism $(\mathrm{F}(1 ; 1260)=0.301, p=0.02)$ than those who determine themselves as other or do not want to tell their gender. The results are interesting, as in practice, all genders have been studying together in mixed classes, and therefore, in theory, should have received the same amount of information of the topics. The significant differences between the evaluations of the knowledge received from school can be partly explained by previous research on motivation and learning that highlight that the more a topic feels personally meaningful and relevant, the more one pays attention to it and seeks for information about it [87].

The results also need to be viewed in the light of the broader societal context. Peace promotion and conflict resolution are themes that are incorporated and debated over in popular youth culture globally [95] and extremism and terrorism are themes that evoke increasing uncertainty and worry in youth globally, but also in Finland [40]. The findings perhaps reflect more broadly the Finnish cultural ethos of peace building and conflict resolution that relate closely to the military service, which becomes a topical theme at adolescence: in Finland, the military service is compulsory for all males between 18 and 60 years of age. The societal pressure for performing military service is strong and while 
more and more contested, it is still considered as a traditional rite of passage and a part of identity for many males [96]. Civil service offers a non-military alternative, but still about $67 \%$ of the conscripts choose attending the military service, typically right after finishing the upper secondary or vocational education. In fact, according to a recent study, Finnish youths' willingness to attend the military service is increasing as a result of global threats, such as terrorism [97]. Theories on the role of motivation in learning [87] may partly explain why boys evaluate having received more knowledge than other genders on peace promotion and conflict resolution and would want to know more about extremism and terrorism. These two themes can be considered closely related to each other and forming the two sides of the same coin. Although a voluntary military service is also offered for females since 1995 and the number of females in the army is steadily increasing [98], the military service is not a popular choice among non-heterosexual and transgender youth, because it is typically seen as a sexist and homophobic context and best suited for heterosexual men [99].

\section{Limitations}

Regarding the limitations of the present study, the data is not representative of all Finnish upper secondary or vocational level students, with $82 \%$ representation of upper secondary institutions in comparison to $18 \%$ from vocational settings, but it has representation from different geographical areas in Finland, both cities and smaller towns and rural areas, and displays varied demographics. Furthermore, we acknowledge that the survey question explored in this study refers to the students' evaluation of the amount of knowledge received of each given topic and cannot be explicitly analysed as an assessment of their opinion about the personal meaningfulness or importance of the topic evaluated. However, the labels of the answer scale ("poorly" and "very well") do include an opinionmapping connotation and thus give a cue of the personal relevance of each given topic to the respondent.

\section{Discussion}

\subsection{Safe Spaces in Education}

In order to prevent hostile attitudes and radicalization in the society, secondary education students in Finland emphasize the role of school as a place to gain objective and diverse knowledge about different cultures, religions, ideologies, values, political systems, and diverse viewpoints. The students regard this knowledge as necessary for the development of awareness, tolerance, perspective-taking, and understanding, especially concerning those who seem different. They consider school as a natural and suitable context for developing these types of cognitive resources, and call for opportunities to reflect and discuss topics related to various cultures, religions, ideologies, values, and other possibly sensitive topics in a safe, non-violent setting, safeguarded by teachers who are urged to make efforts to remain impartial vis-à-vis the various worldviews and perspectives present in the student body. This type of setting could be thought of as a safe space for the exploration and construction of various identities, values, and worldviews, as well as for fostering interpersonal understanding and belonging, and gaining new knowledge.

We suggest that creating safe spaces in schools for discussion and addressing challenging, sensitive topics recognizes safety not only as the absence of harm, such as scorning, bullying, and exclusion, but also as providing students the space to express and discuss their concerns, questions, and opinions, thus giving them the autonomy to become who they are in respect to their identities, values, beliefs, and practices $[65,81,82]$. While the dignity and safety of the identities of all students must be respected by upholding certain rules regarding the freedom of expression, this type of safe space in school allows for the growth of cognitive resources and social skills in students that are key in the prevention of radicalization and extremism [65,100,101]. These resources and skills, also referred to as "transversal competences" in the Finnish national core curriculum [31], enhance 
interpersonal understanding and create means in which dialogue and peaceful co-existence can be advanced on interpersonal, community, and global levels.

\subsection{Sensitive Topics and the Polyphony of Voices in the Safe Spaces}

Regarding the topics of discussion within these safe spaces, the results of our present study demonstrate that topics related to religion, well-being, and health are typically wellcovered in formal education in Finland, as evaluated by the students. However, they also feel that school has not provided them with sufficient knowledge about topics related to extremism and terrorism, and peace promotion and conflict resolution. Nevertheless, these are themes that are omnipresent in the media and surface regularly and spontaneously in daily discussions between the students and the teachers [102]. These sensitive and often identity-related topics evoke curiosity, strong opinions, and feelings, such as fear and uncertainty. It is thus understandable that the students want to discuss these in a safe and calm environment that is conducive to gaining new knowledge, perspectives, and more understanding, as opposed to the discussion platforms on social media that are often tense, polarized, and contribute to even more fear and uncertainty [55]. These themes also become topical at adolescence, as they relate closely to the military service that is compulsory for all young males in Finland. However, it is noteworthy that these are topics that are not allocated to any specific subject in the syllabus, but that may be and typically are addressed within subjects dealing with global and humanitarian issues in general, such as history, civics, religious education, or philosophy. Yet, this depends greatly on the teacher.

While the topics related to extremism, terrorism, and conflicts are stimulating and thought provoking, they may also be challenging to tackle for many teachers $[101,103]$. Indeed, teachers have reported feeling uncomfortable discussing themes related to terrorism and extremist ideologies with children and youth because of lack of substance knowledge about them. For example, they may feel uncertain to explain to the students the motivations of a terrorist to commit an act and kill people [50] or why some people radicalize while others do not [102]. However, if the youth do not receive support and space in school for dealing with their questions, feelings, and thoughts related to complex phenomena and current local or global incidents, such as terrorist attacks or wars, they may be left with no means of dealing with these themes in a safe environment. In this case, there is a risk that the students will go discuss these topics in forums where simplified answers and solutions are offered to complex phenomena and where the justifications of these views may be considerably biased and irrational.

In a large evaluation of those practices that seem to work in the field of PVE-E to decrease black-and-white, dogmatic views, Davies [50] found out that one key factor for success were teachers who are able to address and discuss controversial and difficult topics with the students while promoting not a moralistic, but a critical stance. By discussing sensitive issues, dissenters are given the opportunity to be heard, but also to assess their own beliefs in a new light. Therefore, instead of condemning certain values or worldviews, the discussion should bring forth all voices, not only of the polarized ones who disagree with each other, but also of those who are uncertain or prefer staying in the middle ground [50]. This means that the perspectives and opinions of all students should be heard while also seeking to discover those experiences and feelings that are shared among most of them.

These findings are especially relevant in the Finnish context, as recent studies show that there are many young people in Finland who are socially excluded or feel they do not belong in the school community or in society at large [104]. Creating inclusive safe spaces where the feeling of belonging of students from all backgrounds is fostered and where everyone becomes visible and heard is one way to address this issue at school. The creation of safe spaces in school is a prerequisite for dialogue and discussion that are central tenets in building connections between people having different perspectives [3]. By providing space and opportunities for open, polyphonic, and unprejudiced dialogue between students who 
support different worldviews and ideologies, discussions of nonconformist or deviant ideas and values an be facilitated. Additionally, those ideals of the students that may seem extremist or "adrift" from the society's point of view should be discussed together in school as well as at home, in order to create and restore trust [76,102].

\subsection{Teacher Education and the Scaffolding of Safe Spaces}

While it is easy to agree with the above-described precepts-crystallizing the objectives of 21st century global education [57] - their implementation in the classroom is, however, much more challenging. To create truly and genuinely safe spaces for all students, added sensitivity is required from the teachers first, to recognize the national hegemonies, norms, and values that drive their actions and intentions often unwittingly, for these types of partly unconscious elements and practices play a central role in the construction of the sense of self, belonging, and acceptance of the values, worldviews, and identities of their students. This is where teacher education has a relevant role in preparing student teachers for the field: the ever diversifying student body in terms of worldviews and identities and the suggested PVE-E policies now entering Finnish education make it important to emphasize and practice student teachers' self-reflection on how their own backgrounds, including elements such as their socio-economic position, cultural heritage, and internalized values, shape the way they filter and interpret the world and its actors [4,25]. All teachers act according to their own epistemological understanding of knowledge and truth and this again influences how they interpret teaching and learning situations. These implicit biases can lead to errors in perception and interpretation of the students' actions and utterances [105]. According to studies, youth are very sensitive in detecting teachers' values in the tone of their voice, the conflicts between what they say and what they do, even in their silences $[25,65,81]$.

Teachers are in a key role in creating safe spaces in school for all students to grow cognitively and socially. To do this, metacognition [106], in other words, skills related to "thinking about thinking", needs to be practiced early in teacher education. Only through thorough self-reflection can one become aware of one's own epistemic foundation (values, beliefs, prejudices, and ways of knowledge acquisition), which is a prerequisite for developing ethical sensitivity [107] and understanding of the epistemic foundation of the others [100]. Teachers' awareness of their own epistemic foundation forms the scaffolding for the safe spaces and help them in guiding discussions on sensitive topics in a more objective way. We believe that such issues are becoming acute in an area such as the prevention of radicalization and extremism through education.

\section{Conclusions}

Lately, the diversifying societal value landscape together with the rise of violent events and ideologies $[46,108]$ have created pressure for education to address these challenges and to develop the students' abilities to live and thrive in the diversifying societal settings and in the global world. The polyphony of voices, identities, and diversifying worldviews are increasingly visible in the Finnish classrooms and confrontations between these create tensions also in and through the natural habitat of the youth, social media, which, with its algorithms, increases societal polarization and conflicts between identities and groups of people. However, the ability to coexist peacefully with people with diverging values and lifestyles without forcing anyone into certain societal norms and moulds is necessary to operate in a democratic society. Finnish youth share these thoughts and consider conflict resolution skills as important [40] and necessary in order to prevent hostile attitudes and radicalization [18].

Administered and promoted by governmental policies internationally and more recently also in Finland [42], the prevention of radicalization and violent extremism through education (PVE-E) has emerged as an important objective for educational institutions and, consequently, a novel field of study in the field of educational sciences. The aim of our research project [92] is to explore pedagogical vistas for carrying out PVE-E policies 
in the context of Finnish formal education. This is a particularly topical issue at the moment when young people demonstrate active and democratic citizenship and agency by expressing their concerns, about e.g., climate change or the rights of minorities. It is, however, important to distinguish radicalization into extremism from radical thinking and radicalism, which refer to forward-looking patterns of thought and efforts to reform grievances or other perceived injustices in the mainstream society. The key is to differentiate between violent intentions or acts and peaceful pursuits of social change. Furthermore, in this perspective, it is necessary to strengthen the role of educational institutions in supporting young people to express and act upon their values in peaceful, democratic, and non-violent ways and to prevent them from turning into extremism.

The more media coverage is given to the signs of a world fraught with multiple insecurities and uncertainties, the more attention, we might argue, needs to be drawn in by teachers to the significance of knowledge processing and application. In order to prevent hostility and radicalization, students' minds need to stay as open as possible to new knowledge and perspectives [100]. In light of the findings of our studies [18,43,100], we argue that what schools can do to guide young students to positively and peacefully engage with each other and the society is to offer them a safe environment in which their awareness and understanding can be nurtured, and which gives them tools to assess and analyse the way societal and global phenomena and the (social) media affect their thoughts, emotions, and construction of beliefs, values, and identity. Teachers are important and central facilitators in these processes. Instead of controlling and limiting the topics of discussion, the aim of PVE-E should be to broaden and diversify the epistemic foundation of the students by letting them explore the depths of topics that at surface may seem sensitive, controversial, and potentially dangerous. However, it should be noted that these processes are enabled only by a teacher's self-reflection-the understanding of one's own epistemic foundation-in order to find ways to reduce its potentially harmful effects on the construction of worldviews and identities of the students.

In the development of pedagogical approaches for PVE-E, there is, we here suggest, an important role in understanding the views of the ultimate recipients of such teaching and learning approaches in schools: young people themselves. Our recently published theoretical framing of this issue has, additionally, taken into account the notional "threshold of adversity", those extreme circumstances and situations that push young people beyond the realm of safety into harm's way [100]. Our empirical study, the findings of which we presented here in specific reference to the views of young people in relation to education's role in the prevention of radicalization, makes a contribution to further such understanding of young people's views on these issues. This understanding, we hope, provides pathways to factor in approaches to such pedagogies. Indeed, members of our team have already made contributions to innovative counter-extremism in education policies in Finland. Continuing further to understand young people's views seems an obvious, but often missed, component of policy development in this area, the study of which remains for us ongoing, particularly as part of our 4-year research project Growing up radical? The role of educational institutions in guiding young people's worldview construction.

Author Contributions: Conceptualization, S.B., L.G. and A.K.; methodology, S.B. and P.K.; formal analysis, S.B. and V.S.; investigation, S.B. and P.K.; data curation, S.B. and V.S.; writing-original draft preparation, S.B. and L.G.; writing-review and editing, S.B., L.G. and A.K.; visualization, V.S.; supervision, A.K. and L.G.; funding acquisition, A.K., S.B., P.K. and L.G. Authorship must be limited to those who have contributed substantially to the work reported. All authors have read and agreed to the published version of the manuscript.

Funding: This study was carried out in the research project "Growing up radical? The role of educational institutions in guiding young people's worldview construction" funded by the Academy of Finland 2018-2022 (Grant 315860).

Institutional Review Board Statement: The study was conducted according to the guidelines of the Declaration of Helsinki, and approved by the Ethics Committee of the Humanities and social and 
behavioural sciences at the University of Helsinki and the Departmental Research Ethics Committee at University of Oxford (DREC) (ED-CIA-19-108).

Informed Consent Statement: Informed consent was obtained from all subjects involved in the study.

Data Availability Statement: The data presented in this study are openly available in the Finnish Social Science Data Archive https:/ / www.fsd.tuni.fi/en/, accessed on 28 February 2021.

Conflicts of Interest: The authors declare no conflict of interest.

\section{References}

1. Nurmi, J.; Räsänen, P.; Oksanen, A. The norm of solidarity: Experiencing negative aspects of community life after a school shooting tragedy. J. Soc. Work. 2012, 12, 300-319. [CrossRef]

2. Parker, D.; Lindekilde, L.; Gøtzsche-Astrup, O. Recognising and responding to radicalisation at the 'frontline': Assessing the capability of school teachers to recognise and respond to radicalisation. Br. Educ. Res. J. 2021. [CrossRef]

3. Stephens, W.; Sieckelinck, S.; Boutellier, H. Preventing Violent Extremism: A Review of the Literature. Stud. Confl. Terror. 2019, 44, 346-361. [CrossRef]

4. Niemi, P.-M.; Benjamin, S.; Kuusisto, A.; Gearon, L. How and Why Education Counters Ideological Extremism in Finland. Religions 2018, 12, 420. [CrossRef]

5. Sieckelinck, S.; Kaulingfreks, F.; De Winter, M. Neither Villains nor Victims: Towards an Educational Perspective on Radicalisation. Br. J. Educ. Stud. 2015, 63, 329-343. [CrossRef]

6. Noddings, N. Peace Education. How We Come to Love and Hate War; Cambridge University Press: New York, NY, USA, 2012.

7. Gereluk, D. Education, Extremism and Terrorism. What Should Be Taught in Citizenship Education and Why; Continuum International Publishing Group: Norfolk, Virginia, 2012.

8. García, J.A.R. Islamic religious education and the plan against violent radicalization in Spain. Br. J. Relig. Educ. 2019, 41, 412-421. [CrossRef]

9. Maddock, K. British Values and the Prevent Duty in the Early Years. A Practitioner's Guide; Jessica Kingsley Publishers: London, UK, 2017.

10. Bar-Tal, D.; Rosen, Y.; Nets-Zehngu, R. Peace Education in Societies Involved in Intractable Conflicts. In Handbook on Peace Education; Salomon, G., Cairns, E., Eds.; Routledge: Abingdon, UK, 2009.

11. Di Donato, D.; Grimi, E. (Eds.) Metaphysics of Human Rights1948-2018. On the Occasion of the 70th Anniversary of the UDHR; Vernon Press: New York, NY, USA, 2019.

12. Gearon, L. UNESCO Contemporary Issues in Human Rights Education. From Universal Declaration to World Programme: 1948-2008: 60 Years of Human Rights Education. 2011. pp. 39-104. Available online: http://unesdoc.unesco.org/images/0021/0 02108/210895e.pdf (accessed on 28 February 2021).

13. Gearon, L. Global Human Rights. In The Palgrave International Handbook of Education for Citizenship and Social Justice; Peterson, A., Hattam, R., Zembylas, M., Arthur, J., Eds.; Palgrave Macmillan: London, UK, 2016; pp. 205-228.

14. Gearon, L. Human Rights RIP: Critique and Possibilities for Human Rights Literacies. In Human Rights Literacies: Future Directions; Roux, C., Becker, A., Eds.; Springer: New York, NY, USA, 2019.

15. Gearon, L.; Kuusisto, A.; Musaio, M. The Origins and Ends of Human Rights Education: Enduring Problematics, 1948-2018. In Metaphysics of Human Rights 1948-2018; di Donato, L., Grimi, E., Eds.; Vernon Press: New York, NY, USA, 2019.

16. Gearon, L.; Kuusisto, A.; Matemba, Y.; Benjamin, S.; Du Preez, P.; Koirikivi, P.; Simmonds, S. Decolonising the Religious Education Curriculum: International Perspectives in Theory, Research, and Practice, Special Issue. Br. J. Relig. Educ. 2020, 43, 1-8. [CrossRef]

17. Lehtomäki, E.; Rajala, A. Global education research in Finland. In The Bloomsbury Handbook of Global Education and Learning; Bourn, D., Ed.; Bloomsbury Academic: London, UK, 2020; pp. 105-120.

18. Benjamin, S.; Koirikivi, P.; Kuusisto, A. Lukiolaisnuorten käsityksiä oppilaitosten roolista väkivaltaisen radikalisoitumisen ennaltaehkäisyssä. Kasvatus 2020, 4, 467-480.

19. Malkki, L. International Pressure to Perform: Counterterrorism Policy Development in Finland. Stud. Confl. Terror. 2016, 39, 342-362. [CrossRef]

20. Ghosh, R.; Chan, W.A.; Manuel, A.; Dilimulati, M. Can education counter violent religious extremism? Can. Foreign Policy J. 2016, 23, 117-133. [CrossRef]

21. OECD/PISA. Global Competence Framework. 2018. Available online: https://www.oecd.org/pisa/Handbook-PISA-2018 -Global-Competence.pdf (accessed on 15 February 2021).

22. OSCE. Toledo Guiding Principles on Teaching about Religions and Beliefs in Public Schools. 2007. Available online: http: //www.oslocoalition.org/documents/toledo_guidelines.pdf (accessed on 15 February 2021).

23. Riitaoja, A.-L.; Poulter, S.; Kuusisto, A. Worldviews and Multicultural Education in the Finnish Context: A Critical Philosophical Approach to Theory and Practices. Finn. J. Ethn. Migr. 2010, 5, 87-95. Available online: http://www.etmu.fi/fjem/ (accessed on 23 February 2021).

24. Poulter, S. Kansalaisena Maallistuneessa Maailmassa. Koulun Uskonnonopetuksen Yhteiskunnallisen Tehtävän Tarkastelua. Academic Dissertation, University of Helsinki, Helsinki, Finland, 2013. 
25. Poulter, S.; Riitaoja, A.; Kuusisto, A. Thinking multicultural education 'otherwise'-From a secularist construction towards a plurality of epistemologies and worldviews. Glob. Soc. Educ. 2016, 14, 68-86. [CrossRef]

26. Kuusisto, A.; Poulter, S.; Harju-Luukkainen, H. Worldviews and national values in Swedish, Norwegian and Finnish early childhood education and Care curricula. Int. Res. Early Child. Educ.. in press.

27. Helve, H. A longitudinal perspective on worldviews, values and identities. J. Relig. Educ. 2015, 63, 95-115. [CrossRef]

28. Utriainen, T.; Ramstedt, T. Uushenkisyys. In Monien Uskontojen ja Katsomusten Suomi; Illman, R., Ketola, K., Latvio, R., Sohlberg, J., Eds.; Kirkon Tutkimuskeskuksen Verkkojulkaisuja, Nro 48, Kirkon Tutkimuskeskus: Tampere, Finland, 2017 ; pp. $213-223$.

29. Cornelio, J.; Gauthier, F.; Martikainen, T.; Woodhead, L. (Eds.) Routledge International Handbook of Religion in Global Society; Routledge: Abingdon, UK, 2020.

30. Tirri, K. Finland-Promoting ethics and equality. In Research for CULT Committee-Teaching Common Values in Europe: Study; Structural and Cohesion Policies B; Veugelers, W., de Groot, I., Stolk, V., Eds.; European Parliament: Brussels, Belgium, 2017; pp. 83-90. [CrossRef]

31. NCCBE. National Core Curriculum for Basic Education. Finnish National Agency for Education. Finnish Education in a Nutshell. 2014. Available online: https:/ / www.oph.fi/en/statistics-and-publications/publications/finnish-education-nutshell (accessed on 15 February 2021).

32. Statistics Finland. Immigrants in the Population. 2019. Available online: https://www.stat.fi/tup/maahanmuutto/ maahanmuuttajat-vaestossa_en.html (accessed on 7 March 2021).

33. SUOL. Association of Teachers of Religious Education in Finland. Religious Education in Finland. 2019. Available online: https: / / www.suol.fi/index.php/religious-education-in-finland (accessed on 7 March 2021).

34. Ubani, M.; Hyvärinen, E.; Lemettinen, J.; Hirvonen, E. Dialogue, Worldview Inclusivity, and Intra-Religious Diversity: Addressing Diversity through Religious Education in the Finnish Basic Education Curriculum. Religions 2020, 11, 581. [CrossRef]

35. Åhs, V.; Poulter, S.; Kallioniemi, A. Preparing for the world of diverse worldviews: Parental and school stakeholder views on integrative worldview education in a Finnish context. Br. J. Relig. Educ. 2017, 41, 1-12. [CrossRef]

36. Statistics of Finland. Number of Members of the Evangelic Lutheran Church. 2019. Available online: https://www.stat.fi/tup/ suoluk/suoluk_vaesto.html (accessed on 8 March 2021).

37. Lauritzen, S.M.; Nodeland, T.S. What happened and why? Considering the role of truth and memory in peace education curricula. J. Curric. Stud. 2017, 49, 437-455. [CrossRef]

38. Jerome, L.; Elwick, A. Teaching about terrorism, extremism and radicalisation: Some implications for controversial issues pedagogy. Oxf. Rev. Educ. 2020, 46, 222-237. [CrossRef]

39. Uusitalo, N.; Valaskivi, K. The Attention Apparatus: Conditions and Affordances of News Reporting in Hybrid Media Events of Terrorist Violence. J. Pr. 2020, 1-19. [CrossRef]

40. Youth Barometer. 2018. Available online: https://tietoanuorista.fi/nuorisobarometri/nuorisobarometri-2018/ (accessed on 11 March 2021).

41. Youth Barometer. 2016. Available online: https://tietoanuorista.fi/nuorisobarometri/nuorisobarometri-2016/ (accessed on 11 March 2021).

42. Finnish Ministry of the Interior. National Action Plan for the Prevention of Violent Radicalisation and Extremism. 2020. Available online: https://julkaisut.valtioneuvosto.fi/bitstream/handle/10024/162073/SM_2020_1.pdf? sequence=4\&isAllowed= y (accessed on 11 March 2021).

43. Koirikivi, P.; Benjamin, S.; Kuusisto, A.; Gearon, L. Youths' resilience and wellbeing in school-based prevention programs. An Investigation from the Finnish Context. In press.

44. Youth Barometer. 2019. Available online: https://tietoanuorista.fi/nuorisobarometri/nuorisobarometri-2019/ (accessed on 16 March 2021).

45. Statistics Finland. 2020. Available online: https://www.stat.fi/tietotrendit/artikkelit/2020/nuorten-rikollisuus-on-laskussamutta-pieni-joukko-nuorista-tekee-yha-enemman-ja-vakavampia-rikoksia/ (accessed on 11 March 2021).

46. Kotonen, T. The Soldiers of Odin Finland: From a local movement to an international franchise. In Vigilantism against Migrants and Minorities, Routledge Studies in Fascism and the Far Right; Bjørgo, T., Mareš, M., Eds.; Routledge: Abingdon, UK, 2019; pp. 241-256. [CrossRef]

47. Alava, S.; Frau-Meigs, D.; Hassan, G. Youth and Violent Extremism on Social Media: Mapping the Research; UNESCO: Paris, France, 2017.

48. Kuusisto, A.; Gearon, L. The Life Trajectory of the Finnish Religious Educator. Relig. Educ. 2017, 44, 39-53. [CrossRef]

49. Almond, B. Education for tolerance: Cultural difference and family values. J. Moral Educ. 2010, 39, 131-143. [CrossRef]

50. Davies, L. Security, extremism and education: Safe-guarding or surveillance? Br. J. Educ. Stud. 2016, 64, 1-19. [CrossRef]

51. Vallinkoski, K.; Benjamin, S.; Koirikivi, P. Prevention of Violent Radicalisation and Extremism in the Education Sector. In Finnish Ministry of the Interior. National Action Plan for the Prevention of Violent Radicalisation and Extremism 2019-2023. Publications of the Finnish Ministry of the Interior 2020, 3, pp. 74-81. Available online: https://julkaisut.valtioneuvosto.fi/bitstream/handle/ 10024/162200/SM_202... (accessed on 18 March 2021).

52. Grossman, M.; Hadfield, K.; Jefferies, P.; Gerrand, V.; Ungar, M. Youth Resilience to Violent Extremism: Development and Validation of the BRAVE Measure. Terror. Politics Violence 2020, 1-21. [CrossRef] 
53. Aly, A.; Taylor, E.; Karnovsky, S. Moral Disengagement and Building Resilience to Violent Extremism: An Education Intervention. Stud. Confl. Terror. 2014, 37, 369-385. [CrossRef]

54. European Commission. Prevent Strategies of Member States. 2020. Available online: https:/ / ec.europa.eu/home-affairs/whatwe-do/networks/radicalisation_awareness_network/ran-and-member-states/repository_en (accessed on 26 February 2021).

55. Nguyen, C.T. ECHO CHAMBERS AND EPISTEMIC BUBBLES. Episteme 2020, 17, 141-161. [CrossRef]

56. Allport, G.W. The Nature of Prejudice; Perseus Books: Cambridge, MA, USA, 1954.

57. UNESCO. Global Citizenship Education. Topics and Learning Objectives. 2015. Available online: https://unesdoc.unesco.org/ ark:/48223/pf0000232993 (accessed on 17 March 2021).

58. Brace, C.; Bailey, A.R.; Harvey, D.C. Religion, place and space: A framework for investigating historical geographies of religious identities and communities. Prog. Hum. Geogr. 2006, 30, 28-43. [CrossRef]

59. Stump, R. The Geography of Religion: Faith, Place and Space; Rowan \& Littlefield: New York, NY, USA, 2008.

60. Côté-Lussier, C.; Fitzpatrick, C. Feelings of Safety at School, Socioemotional Functioning, and Classroom Engagement. J. Adolesc. Health 2016, 58, 543-550. [CrossRef]

61. Roux, C. (Ed.) Safe Spaces: Human Rights Education in Diverse Contexts; Sense Publications: Rotterdam, The Netherlands, 2014.

62. Gearon, L. Campus Conspiracies: Security and Intelligence Engagement with Universities from Kent State to Counter-Terrorism. J. Beliefs Values 2019, 40. [CrossRef]

63. Gearon, L. Securitisation Theory and the Securitised University: Europe and the Nascent Colonisation of Global Intellectual Capital. Transform. High. Educ. 2019. [CrossRef]

64. Gearon, L. (Ed.) The Routledge International Handbook of Universities, Security and Intelligence Studies; Routledge: London, UK; New York, NY, USA, 2019.

65. Kuusisto, A. The Place of Religion in Early Childhood Education and Care. In The Routledge International Handbook for the Place of Religion in Early Childhood Education and Care; Kuusisto, A., Ed.; Routledge: Abingdon, UK, in press.

66. Sjøen, M.M.; Jore, S.H. Preventing extremism through education: Exploring impacts and implications of counter-radicalisation efforts. J. Beliefs Values 2019, 40, 269-283. [CrossRef]

67. Mattsson, C.; Säljö, R. Violent Extremism, National Security and Prevention. Institutional Discourses and their Implications for Schooling. Br. J. Educ. Stud. 2018, 66, 109-125. [CrossRef]

68. Ragazzi, F. Students as Suspects? The Challenges of Developing Counter-Radicalisation Policies in Education in the Council of Europe Member States; Interim Report; Council of Europe: Strasbourg, France, 2017.

69. Sian, K.P. Spies, surveillance and stakeouts: Monitoring Muslim moves in British state schools. Race Ethn. Educ. 2015, 18, 183-201. [CrossRef]

70. Mattsson, C.; Johansson, T. The hateful other: Neo-Nazis in school and teachers' strategies for handling racism. Br. J. Sociol. Educ. 2020, 41, 1149-1163. [CrossRef]

71. Rousseau, C.; Ellis, B.H.; Lantos, J.D. The Dilemma of Predicting Violent Radicalization. Pediatrrics 2017, 140, e20170685. [CrossRef]

72. Sivenbring, J. Democratic Dilemmas in Education against Violent Extremism. In Policing Schools: School Violence and the Juridification of Youth; Lunneblad, J., Ed.; Springer Nature Switzerland AG: Cham, Switzerland, 2019; pp. 173-186.

73. Faure-Walker, R. Teachers as informants: Countering extremism and promoting violence. J. Beliefs Values 2019, 40, 368-380. [CrossRef]

74. Busher, J.; Choudhury, T.; Thomas, P. The enactment of the counter-terrorism "Prevent duty" in British schools and colleges: Beyond reluctant accommodation or straightforward policy acceptance. Crit. Stud. Terror. 2018, 12, 440-462. [CrossRef]

75. Lorcerie, F.; Moignard, B. L'école, la laïcité et le virage sécuritaire post-attentats: Un tableau contrasté. Sociologie 2017, 4, 439-446. [CrossRef]

76. Van San, M.; Sieckelinck, S.; De Winter, M. Ideals adrift: An educational approach to radicalization. Ethic Educ. 2013, 8, 276-289. [CrossRef]

77. Flensner, K.K.; Von Der Lippe, M. Being safe from what and safe for whom? A critical discussion of the conceptual metaphor of 'safe space'. Intercult. Educ. 2018, 30, 275-288. [CrossRef]

78. Rom, R.B. 'Safe spaces': Reflections on an educational metaphor. J. Curric. Stud. 1998, 30, 397-408. [CrossRef]

79. Bhabha, H.K. The Location of Culture; Routledge: London, UK; New York, NY, USA, 1994.

80. Bhabha, H.K.; Ashcroft, B.; Beck, U.; Young, R.; Ikas, K.; Wagner, G. (Eds.) Communicating in the Third Space; Routledge: New York, NY, USA, 2009.

81. Kuusisto, A. Monikulttuurinen luokkahuone kolmantena tilana? Kasvatus 2020, 51, 204-214.

82. Cavanagh, T.; Macfarlane, A.; Glynn, T.; Macfarlane, S. Creating peaceful and effective schools through a culture of care. Discourse Stud. Cult. Politicscs Educ. 2012, 33, 443-455. [CrossRef]

83. Nasir, N.S.; Al-Amin, J. Creating Identity-Safe Spaces on College Campuses for Muslim Students. Chang. Mag. High. Learn. 2006, 38, 22-27. [CrossRef]

84. Weisse, W. REDCo: A European Research Project on Religion in Education. Relig. Educ. 2010, 37, 187-202. [CrossRef]

85. Hatzichristou, C.; Lianos, P.; Lampropoulou, A.; Stasinou, V. Individual and Systemic Factors Related to Safety and Relationships in Schools as Moderators of Adolescents' Subjective Well-Being During Unsettling Times. Contemp. Sch. Psychol. 2020, 24, 1-14. [CrossRef] 
86. Williams, S.; Schneider, M.; Wornell, C.; Langhinrichsen-Rohling, J. Student's Perceptions of School Safety. J. Sch. Nurs. 2018, 34, 319-330. [CrossRef]

87. Ryan, R.; Deci, E. Self-Determination Theory. Basic Psychological Needs in Motivation, Development and Wellness; Guilford Press: New York, NY, USA, 2018.

88. Niemiec, C.P.; Ryan, R.M. Autonomy, Competence, and Relatedness in the Classroom: Applying Self-Determination Theory to Educational Practice. Theory Res. Educ. 2009, 7, 133-144. [CrossRef]

89. Findikaattori. 2021. Koulutukseen Hakeutuminen 2019. Available online: https:/ / findikaattori.fi/fi/ 42 (accessed on $20 \mathrm{March}$ 2021).

90. Kuusisto, A.; Poulter, S.; Kallioniemi, A. Finnish Pupils' Views on the Place of Religion in School. Relig. Educ. 2017, 112, 110-122. [CrossRef]

91. Virolainen, M.; Tønder, A.H. Progression to higher education from vocational education in Nordic countries: Mixed policies and pathways. In Vocational Education in the Nordic Countries: Learning from Diversity; Jørgensen, C.H., Olsen, O.J., Thunqvist, D.P., Eds.; Routledge: Oxon, UK, 2018; pp. 51-73.

92. Gearon, L. The Totalitarian Imagination: Religion, Politics and Education. In International Handbook of Inter-Religious Education; De Souza, M., Durka, G., Engebretson, K., Gearon, L., Eds.; Springer: Dordrecht, The Netherlands, 2010; pp. $933-947$.

93. Tirri, K.; Kuusisto, E. Finnish student teachers' perceptions on the role of purpose in teaching. J. Educ. Teach. 2016, 42, 532-540. [CrossRef]

94. McGuire, J.K.; Clarke, T.J.; Anderson, C.R.; Russell, S.T. Understanding School Safety for Transgender Youth. California Safe Schools Coalition Research Brief No. 13; California Safe Schools Coalition: San Francisco, CA, USA, 2010.

95. McEvoy-Levy, S. Introduction. In Peace and Resistance in Youth Cultures. Rethinking Peace and Conflict Studies; Palgrave Macmillan: London, UK, 2018. [CrossRef]

96. Salomaa, H. Asevelvollisuus Kansakunnan Rakentajana. Politicsikasta-lehti. 4/2018. 2018. Available online: https:// Politicsikasta.fi/asevelvollisuus-kansakunnan-rakentajana/ (accessed on 3 March 2021).

97. YLE. Survey: Young People's will to Defend Their Country Turned to Growth—Support for Universal Conscription also Rises Sharply. News Article in Finnish. 2020. Available online: https:/ /yle.fi/uutiset/3-11179169 (accessed on 3 March 2021).

98. Maavoimat. Naisten Vapaaehtoiseen Asepalvelukseen Hakeneiden Määrä Kasvussa. 2020. Available online: https://maavoimat. fi/- /naisten-vapaaehtoiseen-asepalvelukseen-hakeneiden-maara-kasvussa (accessed on 3 March 2021).

99. Lehtonen, J. Going to the 'Men's School'? Non-heterosexual and trans youth choosing military service in Finland. Norma 2015, 10, 117-135. [CrossRef]

100. Benjamin, S.; Gearon, L.; Kuusisto, A.; Koirikivi, P. Threshold of Adversity: Resilience and the Prevention of Extremism through Education. Nord. Stud. Educ.. in press.

101. Davies, L. Education and violent extremism: Insights from complexity theory. Educ. Confl. Rev. 2019, 2, 76-80.

102. Vallinkoski, K.; Koirikivi, P.; Malkki, L. "What is this ISIS all about?" Addressing violent extremism with students: Finnish educators' perspectives. Eur. Educ. Res. J. 2021. [CrossRef]

103. Besir, D.S.; Nuray, P. A Convergent Parallel Mixed-Methods Study of Controversial Issues in Social Studies Classes: A Clash of Ideologies. Educ. Sci. Theory Pract. 2018, 18, 119-149.

104. School Health Promotion Study. Finnish Institute for Health and Welfare. 2019. Available online: https://www.julkari.fi/handle/ 10024/140694 (accessed on 8 March 2021).

105. Feucht, F.C.; Brownlee, J.L.; Schraw, G. Moving Beyond Reflection: Reflexivity and Epistemic Cognition in Teaching and Teacher Education. Educ. Psychol. 2017, 52, 234-241. [CrossRef]

106. Maynes, J. Critical Thinking and Cognitive Bias. Informal Log. 2015, 35, 183-203. [CrossRef]

107. Tirri, K. Ethical Sensitivity in Teaching and Teacher Education. In Encyclopedia of Teacher Education; Peters, M., Ed.; Springer: Singapore, 2019. [CrossRef]

108. Findikaattori. 2020. Available online: https:// findikaattori.fi/fi/57\#: \{\}:text=Pahoinpitelyj\%C3\%A4\%20ilmoitettiin\%20vuonna\% 202018\%20yhteens\%C3\%A4,Niit\%C3\%A4\%20ilmoitettiin\%2023\%20700 (accessed on 28 February 2021). 